\title{
Stone Tool Manufacture Strategies and Lithic Raw Material Exploitation in Coastal Patagonia, Argentina: A Multivariate Approach
}

\author{
Marcelo Cardillo and Jimena Alberti \\ IMHICIHU-CONICET, 15 Saavedra Street, 5th. Floor, 1083 Buenos Aires, Argentina \\ Correspondence should be addressed to Marcelo Cardillo; marcelo.cardillo@gmail.com
}

Received 4 June 2013; Accepted 28 August 2013

Academic Editor: Ravi Korisettar

Copyright (C) 2013 M. Cardillo and J. Alberti. This is an open access article distributed under the Creative Commons Attribution License, which permits unrestricted use, distribution, and reproduction in any medium, provided the original work is properly cited.

\begin{abstract}
This paper seeks to characterize strategies of artifact manufacture and lithic raw material exploitation along San Matías Gulf coast, Argentina, using multifactorial and cluster analysis. Multifactorial analysis is a relatively new method that has yet to be used for archaeological analysis; it has the advantage that it allows us to describe data using different groups of qualitative or quantitative variables at the same time. Additionally, cluster analysis was conducted on multifactorial axis in a bid to identify grouping patterns. The results obtained from the combination of these two methods suggest that they may be useful in characterizing technological strategies in the study area. Furthermore, they may also be a powerful exploratory and characterization tool able to generate explanations at low spatial scales. The application of these methods on San Matías Gulf study case suggests that along the western and northern coasts of this Gulf the most important variables in determining differences in resource use were the fragmentation ratio and lithic raw materials used in artifact manufacture.
\end{abstract}

\section{Introduction}

The coast of Río Negro province, Argentina, runs for $380 \mathrm{~km}$ (Figure 1) with an archaeological record ranging from 6000 years ${ }^{14} \mathrm{C}$ BP to the recent Late Holocene $\left(450\right.$ years ${ }^{14} \mathrm{C}$ BP) [1]. Focusing on different research avenues-artifactual, isotopic, archaeofaunistic, bioarchaeological-it has been possible to determine differences in the use of the coastal areas, as well as changes in subsistence strategies over time ([1-6], amongst others).

In this regard, through the study of lithic assemblages from our study area, we have detected variations in the abundance of different stone tool types and debris discard rates. This could be the result of the microenvironmental diversity in the area, of dating issues, and/or due to changes in human diet $[3,7,8]$. In general, although the manufacture of lithic artifacts was mostly expeditive [9], some raw materials such as obsidian, obtained from sources more than $200 \mathrm{~km}$ away, would have been exploited in a much more conservative manner [10]. Probably, the procurement of obsidian would have taken place as part of the regional circuits of mobility along the coastline, as well as through contact and exchange between the different human groups.

Previous studies [3] have shown that a few common tool types dominated the lithic assemblages. Deposits with a greater variety of types were those with the longest chronological occupation and the highest artifactual density [11]. These places, often located near to secondary lithic raw material deposits (and other subsistence resources), were characterized by high flake and core discard ratios. In contrast, low artifact diversity is observed in loci (specific points in space with concentrations of archaeological materials) with difficult access to resources, or those located further than $1 \mathrm{~km}$ away from coastal or cliff areas. It seems that these sites were used for more specific reasons and consequently in a more discontinuous manner [3,11]. This indicates differences in land-use intensity, thereby suggesting that some areas were used in a more persistent form than others $[3,11]$.

The aim of this paper, therefore, is to apply cluster and exploratory multifactorial analyses to the lithic assemblages 

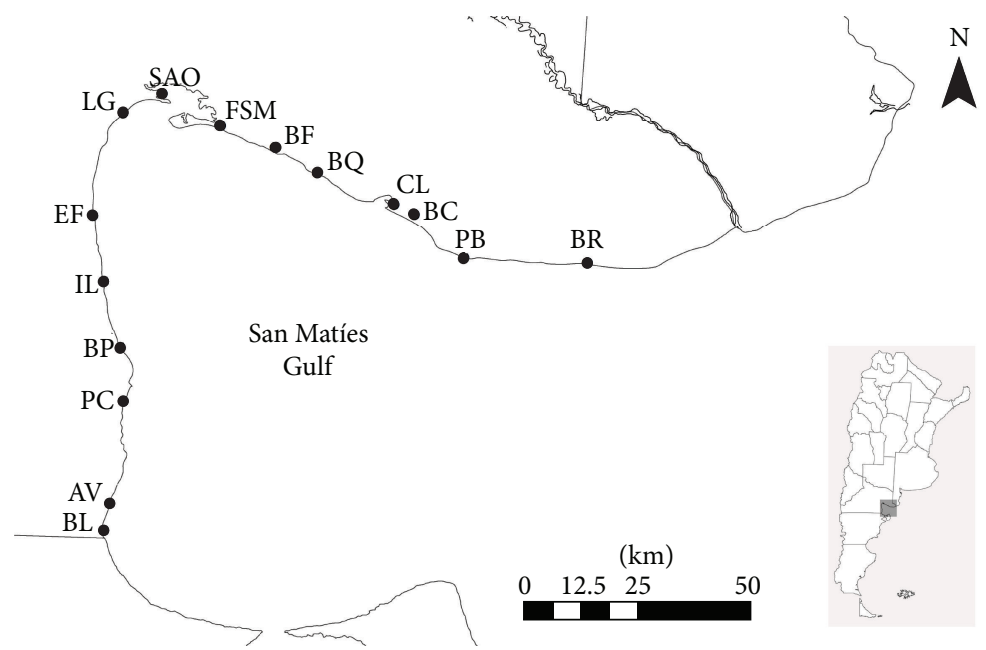

Figure 1: Archaeological sites along the northern and western coasts of San Matías Gulf. *BL: Bahía Lobos; AV: Arroyo Verde; PC: Piedras Coloradas; BP: Bahía Pozos; IL: Islote Lobos; EF: El Fuerte; LG: Las Grutas; SAO: San Antonio Oeste; FSM: Faro San Matías; BF: Bahía Final; BQ: Bajo de la Quinta; CL: Caleta de los Loros; BC: Bahía Creek; PB: Promontorio Belén; BR: Bahía Rosas.

recovered in the study area in order to characterize them according to different spatial scales. To this end, we have employed many different type-groups of variables simultaneously, such as tool diversity, flake and core types, and raw materials used. We believe that in cases such as these, where there is specific data (locus, sector, assemblage) potentially defined from multiple descriptors (raw materials, artifacts, tools, area), the application of multivariate analysis techniques like multifactorial analysis $[12,13]$ has great potential, given that they allow the manipulation of different datasets at a same given time, while permitting a balanced appreciation of each group of selected variables. It's important to highlight that this analysis does not replace other approaches that are fundamental for the technological strategies studies, such as the analyses of provisioning strategies in relation to distances [14-16], the production of cores and flakes and/or the size of the byproducts of the flaking activities [9], or another unior bivariated analyses techniques $[3,11]$. Rather, the greatest potential of this technique is that it is an exploratory one since it allows to detect general patterns of data variation, that can be analyzed in a more specific way with some procedures named before.

\section{Theoretical Framework}

According to Schlanger ([17], see also [18]), an increase or recurrence in the human use of space, at least amongst hunter-gatherer groups, was in part a function of the characteristics of local spaces and of annual or seasonal, fixed and mobile, resource availability. In our case study, the northern coast of San Matías Gulf was an area of heterogeneous resources that would have been used with varying intensity. As we commented earlier, spaces used recurrently possess greater artifact density and, in general, also greater artifact diversity (see [19]), given the heightened probability of tool discard at these places. As a result, loci of high- and lowdensity materials would have formed. In this regard, there is general agreement that to understand how the landscape was used over time, it is necessary to study and compare both large and small lithic assemblages at different landscape locations ([19-21], among others).

Our study is based on Evolutionary Ecology theory ([22, 23]; among others), which suggests that subsistence resource predictability is a structuring factor of technological strategies. In this regard, an important aspect affecting the technological strategies followed by human groups is a risk $[24,25]$, defined as the probability of a loss of resources [2527]. In accordance with this theory, we would expect that in a risky environment with low resource predictability or available energy, technological strategies would demonstrate greater investment in design, maintenance, or functional specificity of toolkit components, in an effort to minimize the risk of loss (see [26]). On this issue, Lanata and Borrero [28] have proposed that the coastal area of Patagonia would be a comparatively low-risk environment, given the annual availability of resources such as mollusks and seal colonies distributed along the coastline, including other resources such as seabirds and fish. Although the study area can be broadly characterized according to the criteria proposed by Lanata and Borrero [28], there are significant differences in the distribution of resources between both the North and West sectors of San Matías Gulf coast. We would expect that these differences would affect the use of these spaces and, in consequence, the richness and composition of lithic assemblages deposited there.

In regards to lithic raw materials, Symons [30] proposes that the study of their availability, variation, and distribution is fundamental to understanding technological variability (see also [31]). This fact, along with the spatial location of the studied loci, was another important aspect of our analysis, insofar as differences in the distribution of some commonly used raw materials in tool manufacture might well have been related to the underlying differences in geological composition between the two different coastal sectors (see infra). 
To recapitulate, we consider that the application of multivariate techniques permits us to model the observational expectations derived from the Evolutionary Ecology theory whilst simultaneously considering multiple lines of evidence.

\section{Spatial and Environmental Settings}

The northern and western coasts of San Matías Gulf display important variation in regards to the availability of faunal, floral, and lithic resources $[1,5,14,32-34]$, related to differences in topographic, geologic, and environmental factors [1].

The northern San Matías Gulf coast (see Figure 1) runs from East to West between the modern city of San Antonio Oeste and El Cóndor sea resort at the mouth of Negro river. A fluvial plain that forms a coast with cliffs characterizes this sector. Nevertheless this coast is broken by a few lowcoast sections (e.g., Caleta de los Loros, Bajo de San Antonio, and Bahía Rosas) [35], where the sea floods inland creating a series of extended bays and marshes [1]. Along this coast, there are active cliffs-about 50 and 60 meters high-that alternate with bays and raised platforms, and also beach ridges and marine terraces covered by aeolian sand deposits and dunes that spread inland, covering and uncovering certain areas of the landscape $[1,5,36]$.

In respect to the western coast, the northern one is richer in resources due to the availability of fresh water in the dune areas, as well as animal resources such as fish, mollusks and sea lions, natural topographic shelters, and lithic raw materials suitable for flaking activities [7, 14, 37]. At present, 50 archaeological loci have been detected, for this sector of the Gulf. These are mainly shell middens composed of two mussel species (Aulacomya Ater and Mytilus edulis), sometimes burned and with evidence of charcoal. Archaeological remains have also been discovered on the terraces surfaces and near the dunes [5]. These various loci have been dated between $c a .6000$ and 450 years ${ }^{14} \mathrm{C} \mathrm{BP}$ [38].

The western coast (see Figure 1) runs from North to South from San Antonio Oeste city to Puerto Lobos, on the border with the Chubut province, and is divided into two areas. The first one, from Punta Sierra northwards were the geology is generally sedimentary providing easy access to the sea $[1,5]$. In the second area, from Punta Sierra southwards, there is a plateau with stepped access to the sea, called Somuncurá plateau [35]. At the South of this point there is a volcanic rocky geology landscape, creating a jagged and broken coastline. This area of the coast is cut by small estuaries - such as the Salado and Verde streams - with sandy beaches and minor dunes. In general, the beaches along the western coast are more regular and have easy access to a wide rocky intertidal, which is not a favored environment for mussel colonies [39].

In the western coast, the prevailing wind is from the West so dune formation is rare, resulting in greater visibility of the archaeological record [36]. Thirty archaeological loci have been identified to date along this coast with a higher concentration of them in the northern sector [5]. Yet the greater lack in resource availability and fresh water in comparison to the northern coast meant that this portion of Río Negro province coast was less intensively used [40]. This lessened intensity of use is reflected in the low number of archaeological sites used recurrently, in the scarcity of shell middens and also in the paucity of the bioarchaeological and faunal evidence [1]. This pattern is also repeated in the diversity and composition of the lithic assemblages (see infra). Therefore, the archaeological signature along the western coast is very different to that of the northern coast, positing for this coast a more sporadic but spatially more extensive human activity. This goes well with the greater environmental homogeneity of this area [1]. The dates obtained for this coast suggest its use around 3000 years ${ }^{14} \mathrm{C}$ BP $[1]$.

The less amount of energy available in the form of basic resources may have influenced the intensity of use of the western coast. In contrast, within an Evolutionary Ecology theoretical framework, the northern coast of the Gulf would have presented a low risk environment given the presence of predictable, yearlong resources such as shellfish. The higher recurrence occupation rate of these northern area relates directly to higher discard rates, resulting in greater tool-type variety (assuming that variety is in turn related to persistence of use and sample size at each loci).

3.1. Raw Materials Availability along the Coastal Area. Most of the lithic raw materials sources along the northern coast of San Matías Gulf are secondary deposits of marine or glacifluvial origin $[32,35]$. The extensive and relatively homogeneous distribution of these deposits implies raw material availability along the whole coastal area, even though raw material distribution and lithology vary considerably [14]. Pebble size ranges between ca. 3 to $20 \mathrm{~cm}$ across its maximum axis. This in turn may have influenced the reduction strategies applied by human groups using these lithic raw materials and, consequently, the fragmentation ratio and the cortex left on the artifacts. As the lithic raw materials sources are ubiquitous and abundant, the availability of lithic material would not have been a risk factor for the human groups that inhabited this area $[14,33]$. Due to this, lithic provision strategies would have been embedded (sensu [41]) within other coastal subsistence strategies, such as shellfish procurement, and fishing.

The situation along the western coast is very different; here, the primary sources are formed by porphyritic outcrops with siliceous veins and blocks of variable knapping quality (sensu [42]). In addition, chalcedony pebbles of excellent quality exist as primary and secondary deposits forming spatially discrete outcrops. Nevertheless, these secondary coastal deposits in particular are distributed in a more heterogeneous and less densely way than those along the northern coast [32]. Concerning the use of lithic raw material sources, we have not documented a raw material-use economy or planned raw material conservation strategies.

The homogeneity observed on these two coasts of San Matías Gulf in the use and discard patterns of lithicsstrategies of exploitation and reduction of cobbles were similar irrespective of raw material-was in sharp contrast to the variability in lithic raw material discard $[3,32]$. The varying frequencies in lithic raw material detected on these 
two coasts could be due to the local use of material along the western coast and to the transportation of nonlocal material along the northern one [32]. The high discard ratio of cobbles of lithic material not available in close proximity to the loci along the northern coast could be related to space provisioning strategies [41] regarding the use of the space for future visits to the area. However, we would expect that different lithic raw material availability and distribution would affect stone tool diversity and composition. In this regard, the relationship between raw material, tools, core, and flake density and abundance was explored through multivariate methods in order to take into account spatial heterogeneity in raw material distribution and variability.

\section{Methods}

Frequency and composition are two basic attributes used to describe archaeological assemblages, particularly in regards to technological analysis (see $[43,44]$ ). As such, this data has certain properties that differentiate it from other quantitative data, such as the relation between mean and variance [45], the asymmetry in the distributions, and the double " 0 " effect on the application of symmetric similitude/dissimilitude measures, such as Euclidean distance. In the first place, the power function relation amongst the mean and the variance implies that sets with a greater frequency will have a greater variance. This phenomenon generates distortions in the multivariate analysis, especially those based on Euclidian metrics, for instance, Principal Component Analysis (PCA), because the first axis tends towards the most abundant artifact classes, therefore underestimating the value of rare or scarce tools.

Another important aspect is that, when symmetric distances, such as Euclidean or Chord's, are used, the shared absences (double " 0 ") are interpreted as similarities and not as lack thereof, which results in the smallest sets tending to cluster together on the basis of absent features rather than because of their typological diversity. An available option towards controlling the sample size effect thereby allowing comparisons among samples of different size is to use transformations $[46,47]$. One of the most effective methods when the Euclidean distance is selected is the use of proportions $[47,48]$.

This paper then explores the use of multivariate techniques on various abundance datasets, which are transformed into proportions, alongside a small set of category variables. To this end, each locus or assemblage in the sample $(n=$ 59) represents one or more sampling units performed on archaeological surface material $[4,6]$. The location of these sample units was chosen taking into account the abundance of the different tool types, or artifactual categories, and lithic raw materials.

Each of these units has been described by active (used directly during the multivariate analysis) and passive variables (used a posteriori as descriptive tools). Four datasets of actives variables were generated: tools ( $n=10$ descriptors), flakes ( $n=2$ descriptors), cores ( $n=6$ descriptors), raw materials ( $n=9$ descriptors); and two of passive variables: the proportion of fragmented artifacts over
TABLE 1: Absolute and relative frequencies of the different types of tools, lithic raw materials, and the fragmentation in the sample analyzed. The total $n$ of each sample is also shown. ${ }^{*}$ The frequency of artifacts and raw materials differs because the unidentified artifacts have been eliminated of the table. DFGR: dark fine-grained rocks (sensu [29]). "Expedient core" signifies a core with four or less scars.

\begin{tabular}{|c|c|c|}
\hline & $n$ & $(\%)$ \\
\hline \multicolumn{3}{|l|}{ Tools } \\
\hline Chopping tool & 6 & 2.29 \\
\hline Denticulate & 69 & 26.34 \\
\hline Used flake & 32 & 12.21 \\
\hline Expedient tool & 40 & 15.27 \\
\hline Notch & 24 & 9.16 \\
\hline Hammer & 9 & 3.44 \\
\hline Bifacial tool & 19 & 7.25 \\
\hline Burin-like tool & 10 & 3.82 \\
\hline Side scraper & 11 & 4.20 \\
\hline End scraper & 42 & 16.03 \\
\hline Total tools & 262 & 100 \\
\hline \multicolumn{3}{|l|}{ Flakes } \\
\hline Internal flakes & 4266 & 80.02 \\
\hline External flakes & 1065 & 19.98 \\
\hline Total flakes & 5331 & 100 \\
\hline \multicolumn{3}{|l|}{ Cores } \\
\hline Bipolar & 60 & 13.73 \\
\hline Discoidal & 67 & 15.33 \\
\hline Expedient & 97 & 22.20 \\
\hline Tested piece & 37 & 8.47 \\
\hline Polyhedral & 166 & 37.99 \\
\hline Unidirecional & 10 & 2.29 \\
\hline Total cores & 437 & 100 \\
\hline \multicolumn{3}{|l|}{ Raw materials } \\
\hline Chalcedony & 902 & 14.12 \\
\hline Quartz & 11 & 0.17 \\
\hline Jasper & 52 & 0.81 \\
\hline Opal & 575 & 9.00 \\
\hline DFGR & 2630 & 41.16 \\
\hline Sedimentary rocks & 22 & 0.34 \\
\hline Siliceous rocks & 1543 & 24.15 \\
\hline Volcanic rocks & 622 & 9.73 \\
\hline Xilopal & 33 & 0.52 \\
\hline Total raw materials & $6390^{*}$ & 100 \\
\hline \multicolumn{3}{|l|}{ Passive variables } \\
\hline \multicolumn{3}{|l|}{ Mean fragmentation } \\
\hline Northern coast & 3543 & 60.97 \\
\hline Western coast & 303 & 59.64 \\
\hline Total sector & 6390 & 100 \\
\hline
\end{tabular}

the total number of artifacts analyzed, and a categorical variable (area) which describes if the sample comes from the North or the West coast (see Table 1). Is important to clarify that in order to avoid over-representation of categories, we have only included complete flakes or broken flakes with platform, and that broken tools have been counted only once. Each dataset has varying quantity of descriptors and different levels of internal homogeneity. The tool matrix was 
the most heterogeneous given that it was influenced by the low frequency of tools in the sample and by the relationship between the diversity and the size of the samples. In this context, the application of multifactorial analysis can be a useful exploratory and analytical tool $[12,13,48]$, given that it permits the description of individual items considering different sets of variables, thus balancing the influence of the different groups at the same time and so allowing direct comparisons. To determine tools, flakes, and cores types we followed the convention established by Aschero [49, 50]. It is also important to note that we have used this convention in order not to undertake functional but rather morphological analysis.

Multifactorial analysis (MFA) performs a PCA in each group in the case of the continuous variables, and a correspondence analysis in the case of qualitative variables. Firstly, this was carried out on each dataset independently, retaining the variables that explain a significant portion of the variance, so that subsequently a global analysis incorporating all these components could be undertaken. In each case, values were assigned to each group of variables according to the first Eigenvalue for the PCA of each group. Thus, the maximum axial inertia of each group of variables is equal to $1[12,13]$. If all the sets of variables are introduced as active elements, without balancing their influence, a single set can over-contribute to the make-up of the first axis. Using the maximum variance axis to standardize each group of variables, the global analysis balanced each contribution according to total variation, and thus the structure of each group was respected $[12,13]$. As in other ordination methods, this analysis is correlative because it excluded the possibility of causal influence on a dataset by another [48], yet one or more explicative variable vectors can be fitted a posteriori. As in common PCA, the correlation between the original variables and the new axis can be graphically or numerically represented. Also, the similarity between the geometrical representations derived from each group of variables was measured by the RV coefficient, which varies between 0 and 1 . In this case, $P$ values were obtained by permutations following the procedure suggested by Borcard et al. [48].

Hierarchical cluster analysis on principal components was used [51] in order to visualize and describe discontinuities (groups) among the first axis of the MFA. Regarding cluster analysis, the first five dimensions were taken, which, in this case, comprised $70 \%$ of the total variation (see Section 5). This method partitions $n$ elements into clusters by means of Ward's minimum variance criteria. In a similar fashion to PCA, the Ward method uses Euclidean distances. An algorithm that minimized the multidimensional variance (total inertia) was also implemented; in this manner, the groups obtained were as internally homogeneous as possible, and the inertia between them was reduced to a minimum. To sum up, this method allowed us to reduce the number of desired dimensions for the MFA to only one, resulting in a complementary application that increased the explanatory use of the method, especially in cases where the original matrix was heterogeneous (see infra).

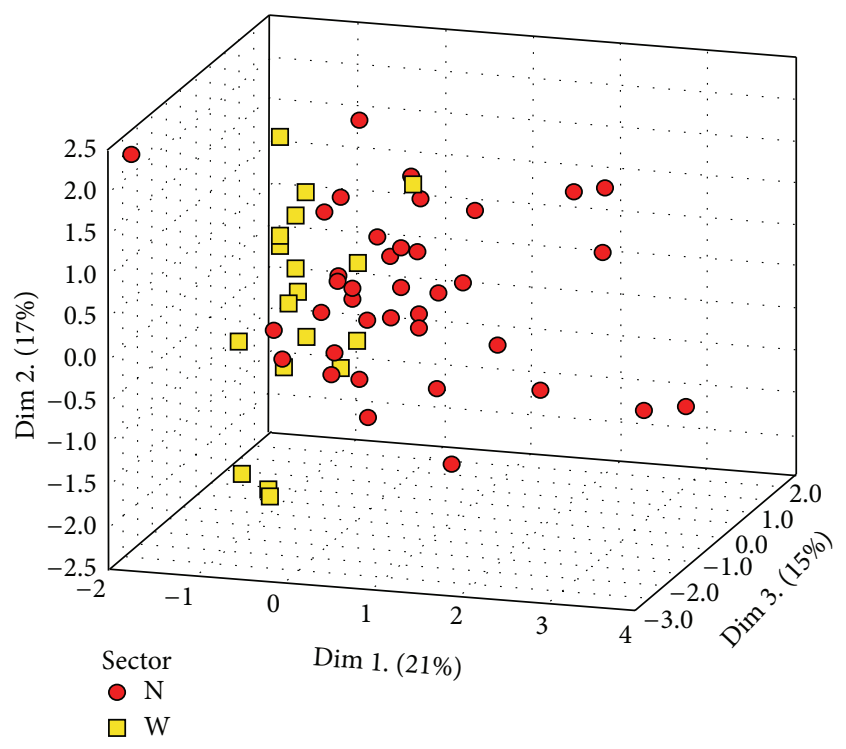

FIGURE 2: First three axes of MFA ordination showing differences in North and West sample distribution in the ordination space.

The selection of the optimal number of clusters was based on the determination of the minimum number of groups in such a manner that when a new cluster was added, the observed inertia was the maximum in the minimum possible number of divisions. The cluster cut-point was taken when the inertia between groups would have been reduced if a new division was introduced into the set [51].

Finally, the V-test was used as a descriptive tool to detect which variables or sets of them played a statistically significant part in the observed grouping patterns. In the case of the continual variables, this test compared the deviation among the average of each category for the whole set, to the average of each group, under the null hypothesis that the average of each category is equal to the general average. A test value over 1.96 correspondeds to a $P$ value lower than 0.05 . The value indicates if the average of each cluster is higher or lower than the general average $[48,52]$.

To run all these tests, we used the statistical package FactoMineR [53] implemented by R 2.13.0 [54]. These tests evaluated the relevance of multifactorial and cluster analyses as a tool in comparing different groups of variables measured as relative abundances (proportions) towards interpreting the technological organization of the hunter-gatherer groups that inhabited San Matías Gulf coast during Middle and Late Holocene $\left(6000-450{ }^{14} \mathrm{C}\right.$ years BP).

\section{Results}

The factorial analysis suggested that the first two axes comprehended $40 \%$ of the total variation among the groups of variables (Figure 2). The loadings indicated that the distributions along the first dimension was mostly explained by tool abundance (52\%), followed by raw materials ( $43 \%)$, cores $(4.17 \%)$, and flakes (1.43\%). The second axis (Figure 2) was mainly explained by flakes (67\%) and cores (14\%), followed by raw materials (11\%) and tools (5.6\%). Among the active 


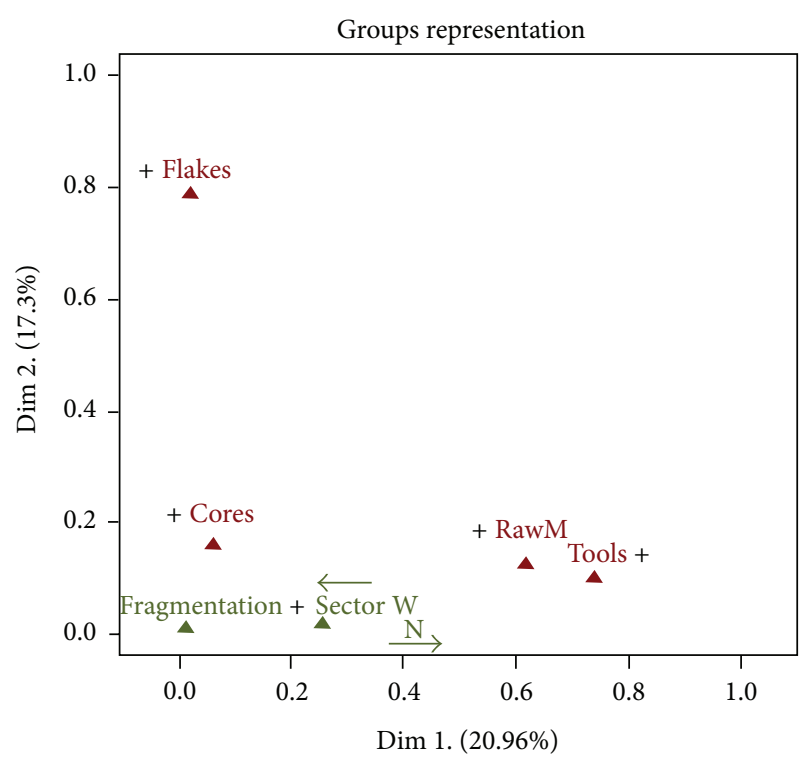

FIGURE 3: Groups representation related with two first MFA axes.

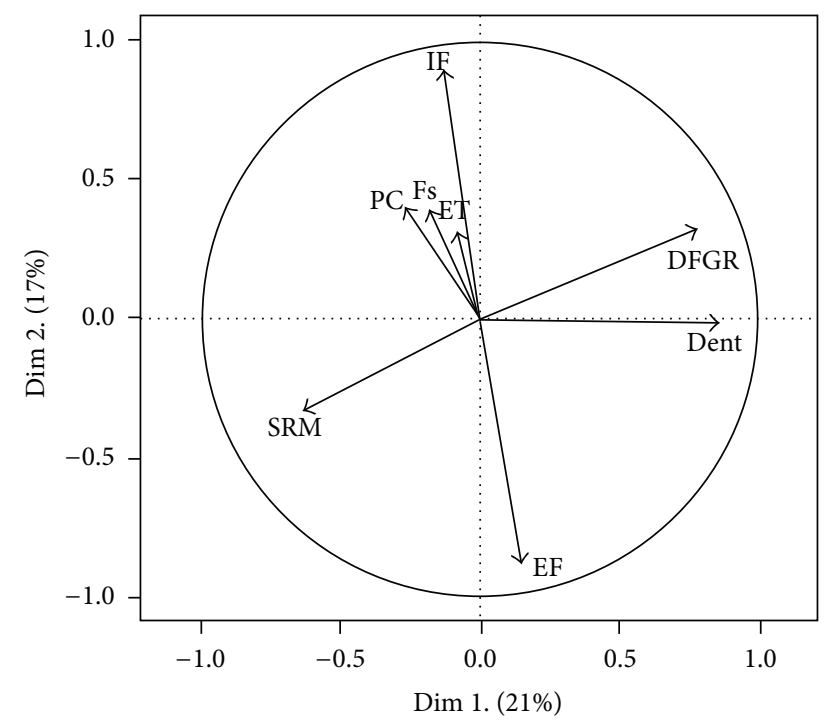

FIgURE 4: Correlation circle. Only variables with significant correlation with the two first axes are shown. ${ }^{*} \mathrm{PC}$ : polyhedral cores; Fs: end scrapers; ET: expedient tools; EF: external flakes; IF: internal flakes; Dent: denticulate tool; SRM: siliceous rocks; DFGR: dark fine-grained rocks.

variables (tools, raw materials, flakes, and cores), only tools and raw materials possessed a significant correlation $(\mathrm{RV}=$ $0.17, P<0.01$ ) (Figure 3 ), while there was a low correlation among the passive variable area and raw materials $(\mathrm{RV}=$ $0.35)$, and area and fragmentation $(\mathrm{RV}=0.17)$. The probability for passive variables has not been estimated. This suggested a relationship between lithic raw material selection and at least some of the tools that were manufactured. Also the distribution of cases in ordination space suggested differences between North and West samples (Figure 2), relating to the optimal location of each group of variables (Figures 3 and 4 ).
TABLE 2: Correlation between the first two axes of the MFA and the analyzed variables. Only significant correlations are shown $(P<$ 0.05).

\begin{tabular}{lcc}
\hline & Correlation & $P$ value \\
\hline Dim. 1 & & \\
Denticulate & 0.851 & $P<0.01$ \\
DFGR & 0.785 & $P<0.01$ \\
End scraper & -0.279 & $P<0.01$ \\
Siliceous & -0.650 & $P<0.01$ \\
Dim. 2 & & \\
External flakes & 0.889 & $P<0.01$ \\
End scraper & 0.413 & $P<0.01$ \\
Polyhedral core & 0.394 & $P<0.01$ \\
DFGR & 0.315 & $P<0.01$ \\
Expedient tools & 0.307 & $P<0.01$ \\
Siliceous & -0.330 & $P<0.01$ \\
Internal flakes & -0.888 &
\end{tabular}

Regarding the variables, we have described the ones that possessed a substantial weight in the observed ordination. Only those with significant correlation with the first two axes (Table 2) were selected. The greatest contribution to the make-up of the first axis was given by the high quantity of DFGR (dark fine-grained rocks, sensu [29]) and denticulates, two variables that had a significant correlation between them $(r=0.50, P<0.01)$ and, to a lesser extent, siliceous rocks and end scrapers. The second axis was mainly explained by the external (negative values) and internal (positive values) flake proportions, with a negative correlation between each other $(r=-0.90, P<0.01)$. To a lesser extent, we observed significant correlation between other categories, such as chopping tools and the use of volcanic rocks, burinlike tools and siliceous rocks, and raw materials and cores, although their input to the variance explained by the first two axes was not significant.

Using the first five axes (70\% of the total variance) of the multifactorial analysis, we run a cluster analysis using the minimum variance Ward method, in order to achieve a more detailed understanding of the total percentage variance of the sample, and to analyze patterns of data grouping. The cut-off was selected in such a manner so that the analysis would be able to maximize the variance explained in the least amount of possible partitions (see Figure 5). The pattern of data grouping showed three groups of decreasing size (see Figures 5 and 6).

Using the $\mathrm{V}$-test on the variables, those that possessed significant roles in group definition were extracted (Table 3). The first cluster had a greater average proportion of cores and raw material of good flake quality (DFGR and volcanic rocks) from the immediate proximity. The second group had a greater proportion of polyhedral cores, high relative fragmentation, and a greater proportion of denticulates (Table 3 ). The third cluster also had a higher proportion of denticulates, associated to DFGR and chalcedony, of high flake quality (Table 3). Finally, in general terms, the clusters separated the cases according to the areas where they belonged (North or 


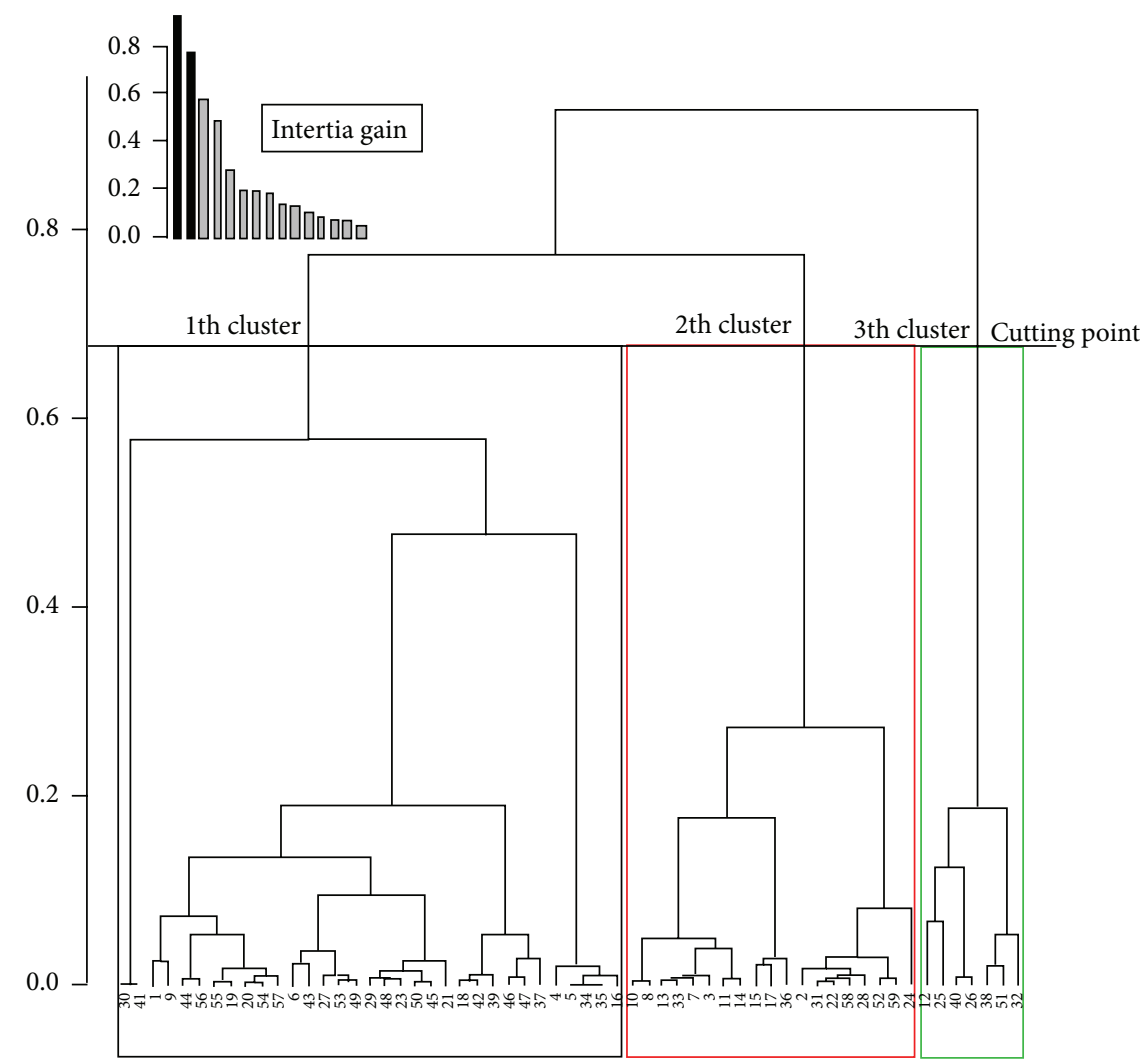

FIGURE 5: Result of the grouping made by the cluster analysis using the Ward method. Cutting point indicates the minimum possible groups that maximized the explained variance.

TABLE 3: $V$-test over the medium proportion of the variables that were analyzed for each cluster defined using the Ward method. Only the statistically significant proportions are shown $(P<0.05)$.

\begin{tabular}{|c|c|c|c|c|c|c|}
\hline & $V$-test & Mean in category & Overall mean & sd in category & Overall sd & $P$ value \\
\hline \multicolumn{7}{|l|}{ Cluster $1(n=32)$} \\
\hline Expedient cores & 2.631 & 0.178 & 0.117 & 0.226 & 0.194 & $P<0.001$ \\
\hline Discoidal cores & 2.608 & 0.193 & 0.119 & 0.292 & 0.237 & $P<0.001$ \\
\hline Bipolar cores & 2.396 & 0.172 & 0.108 & 0.270 & 0.222 & $P<0.001$ \\
\hline Tested pieces & 2.278 & 0.041 & 0.023 & 0.084 & 0.065 & $P<0.001$ \\
\hline Volcanic rocks & 2.132 & 0.093 & 0.070 & 0.110 & 0.091 & $P<0.001$ \\
\hline DFGR & 2.941 & 0.183 & 0.278 & 0.182 & 0.270 & $P<0.001$ \\
\hline Polyhedral cores & 5.443 & 0.138 & 0.398 & 0.164 & 0.396 & $P<0.001$ \\
\hline \multicolumn{7}{|l|}{ Cluster $2(n=19)$} \\
\hline Polyhedral cores & 6.164 & 0.863 & 0.398 & 0.167 & 0.396 & $P<0.001$ \\
\hline Fragmentation & 2.293 & 0.619 & 0.5195 & 0.188 & 0.239 & $P<0.001$ \\
\hline Denticulates & 2.651 & 0.045 & 0.245 & 0.114 & 0.396 & $P<0.001$ \\
\hline \multicolumn{7}{|l|}{ Cluster $3(n=8)$} \\
\hline Denticulates & 6.231 & 1.063 & 0.245 & 0.390 & 0.396 & $P<0.001$ \\
\hline DFGR & 4.454 & 0.676 & 0.278 & 0.259 & 0.270 & $P<0.001$ \\
\hline Chalcedony & 2.063 & 0.065 & 0.157 & 0.056 & 0.135 & $P<0.001$ \\
\hline
\end{tabular}

West $\left(X^{2}=7.53, P=0.02\right.$, exact $\left.P=0.03\right)$. The large majority of the northern coast cases were concentrated in the first cluster, while those of the western coast were distributed mainly in the second and, to a less extent, in the first cluster. The third cluster had only 8 individuals, 7 of which were from the northern coast.
Finally, a V-test was run between the proportions of the different categories of both coasts, in order to evaluate the direct contribution of each variable to the differences observed between the areas (see Table 4). The results demonstrated that the raw material was the first important group of variables that influenced ordination and clustering patterns. 
TABLE 4: $V$-test over the mean proportion of the different variables that were analyzed for the northern and western coast. Only the statistical significant proportions are shown $(P<0.05)$.

\begin{tabular}{|c|c|c|c|c|c|c|}
\hline & $V$-test & Mean in category & Overall mean & sd in category & Overall sd & $P$ value \\
\hline \multicolumn{7}{|l|}{$\mathrm{N}$} \\
\hline DFGR & 3.771 & 0.367 & 0.278 & 0.270 & 0.270 & $P<0.001$ \\
\hline Opal & 2.367 & 0.133 & 0.103 & 0.165 & 0.150 & $P<0.001$ \\
\hline Polyhedral cores & -2.401 & 0.316 & 0.398 & 0.377 & 0.396 & $P<0.001$ \\
\hline Fragmentation & -2.950 & 0.46 & 0.519 & 0.2061 & 0.22898 & $P<0.001$ \\
\hline Siliceous & -4.706 & 0.241 & 0.364 & 0.241 & 0.300 & $P<0.001$ \\
\hline \multicolumn{7}{|l|}{ W } \\
\hline Siliceous & 4.706 & 0.644 & 0.364 & 0.225 & 0.300 & $P<0.001$ \\
\hline Fragmentation & 2.950 & 0.653 & 0.519 & 0.222 & 0.228 & $P<0.001$ \\
\hline Polyhedral cores & 2.401 & 0.587 & 0.398 & 0.372 & 0.396 & $P<0.001$ \\
\hline Opal & -2.367 & 0.032 & 0.103 & 0.070 & 0.150 & $P<0.001$ \\
\hline DFGR & -3.771 & 0.077 & 0.278 & 0.118 & 0.270 & $P<0.001$ \\
\hline
\end{tabular}

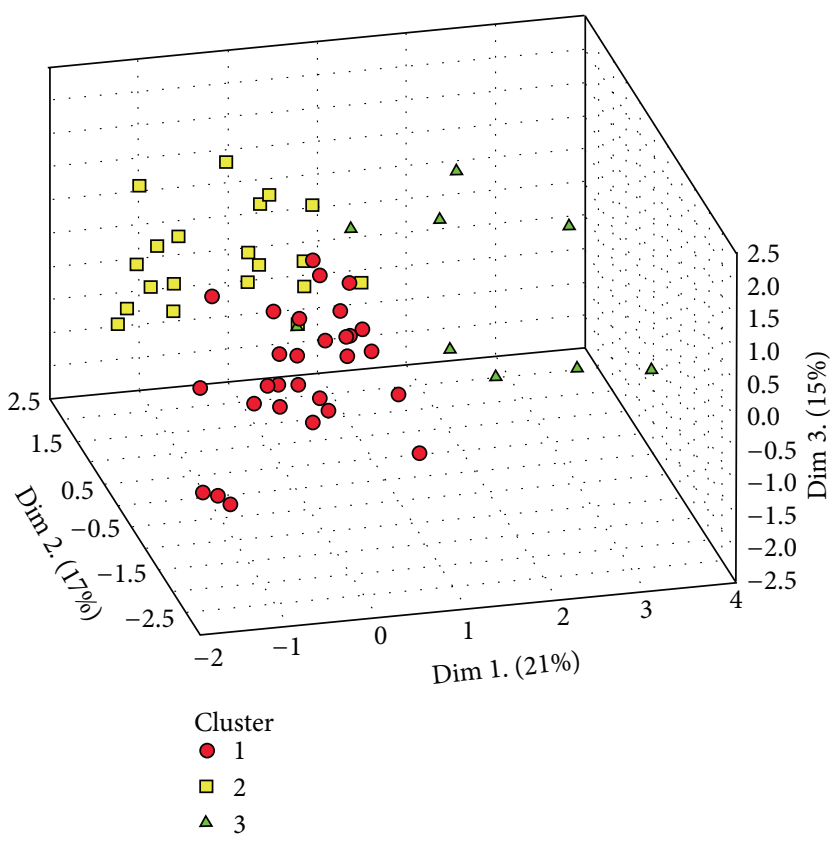

FIgURE 6: Ordination of the first axis of MFA showing the clusters defined by the Ward method. The graph was arbitrarily rotated so as to better view the case distribution. The first cluster of the analysis performed above (see Figure 5) is shown colored in yellow.

The second important group of variables was the fragmentation ratio; the average for this category was lower along the northern coast (mean $=0.46$ ) than along the western one (mean $=0.65)$. Also, the northern coast had a lower average of polyhedral cores ( 0.31$)$ than the western coast (0.58).

\section{Discussion and Conclusions}

The analyses indicate that three types of loci could be differentiated after using the MFA and the cluster analysis methods. These methods employed a series of variables that had significant diversity between the subsets studied. The biggest cluster $(n=31)$ is characterized by the use of the most abundant good flake quality local lithic raw material (DFGR) and by the highest average type of cores related to different reduction stages and exploitation activities (polyhedral and bipolar cores). A second cluster $(n=19)$ was differentiated from the first one because it has a higher fragmentation ratio and denticulate tools. Finally, there is a third cluster $(n=8)$ that has material of excellent flake quality (chalcedony) and a high proportion of denticulates and DFGR locally available. In regard to the groups of variables, there is a covariation in the type of lithic raw material that was used and the manufacture of different types of tools, especially denticulate; the same pattern was also observed in end scrappers, burinlike tools, and chopping tools. So, as a conclusion, the results suggest that it is possible to characterize groups of loci in relation with some types of cores, the presence of diagnostic tools (denticulates) and the raw material used average (good versus excellent flake quality), as well as the fragmentation ratio.

When we took into account the relative value of both coasts, we observe that the raw materials used and the fragmentation ratio are the main variables for discriminating between the northern and the western coast (see Table 2). Nevertheless, the separation into three clusters also permitted the characterization of both coasts, because both of them were included into different subgroups. Fragmentation ratio appears to be a counter-intuitive variable because both areas demonstrated similar values of this variable, but mean fragmentation is higher along the western coast, were some loci have $100 \%$ of the tools broken. This means that more fragmentation heterogeneity and extreme values were observed along the western coast. It is important to note that fragmentation ratio could be strongly related to the size of the pebbles that were used and the brittleness of each rock type. In the case of the western coast, a greater fragmentation ratio was expected given the form in which the lithic raw materials mainly appear (secondary sources with pebbles not bigger than $20 \mathrm{~cm}$ long).

If the fragmentation ratio that we observe works as a useful variable distinguishing between the two coastal areas, it might be explained by site reoccupation and reuse of 
previously abandoned artifacts, by the fracture characteristics of the lithic raw material in the area, or by a consequence of blank reduction and transportation strategies. Nevertheless, to thoroughly treat these varying hypotheses it would be necessary to control taphonomic processes in both of these coastal areas [55] in order to rule out any other nonhuman mechanisms that could produce similar results in the archaeological record. We will be following this line of research in future studies on San Matías Gulf coast.

Even though we proposed that reoccupation and use of sites along the northern coast, where most of the raw materials-such as DFGR - were locally available, was higher than along the western coast, the western coast still has a higher fragmentation ratio. Furthermore, this higher fragmentation ratio in the loci located on the western coast occurred on tools manufactured on siliceous rocks such as chalcedonies, jaspers, and opals, all of which fracture much less easily than DFGR. For the western coast, a sporadic or nonpermanent occupation of the archaeological sites was hypothesized based on the particular characteristics of the area: the low general productivity in regards to sea and terrestrial fauna, as well as plant resources, the scarcity of fresh water and the low number of good quality topographic shelters $[1,40]$. Concerning lithic raw materials use, it is possible then that human groups ventured into this area in order to obtain excellent flake quality material, not found along the northern coast [14]. In this manner, we can get to grips with the factors underlying the fragmentation ratio found on the western coast.

Taking this further, we might theorize that the area was mined for blanks and cores that were then transported to the northern coast. Supporting this theory is the fact that tools and cores of siliceous rocks, opal, chalcedony, and jasper are frequently found along the northern coast, where these raw materials appear naturally in very low proportions, mainly on the coast as a consequence of littoral drift processes. Examining the first cluster (Figure 5), in which most of the northern coast loci are grouped, we observe that the variety of cores at these sites indicates the presence of all the reduction sequence stages of the tools recovered (for discussion on this subject see [44]). Recurrence in the use of these northern sites was much higher than those along the western coast, which group mostly within the second cluster, characterized by polyhedral cores, broken artifacts and denticulates. Along the western coast, then, probably the groups used the space in order to exploit certain resources, to diversify toolkits through the exploitation of local rocks (such as chalcedonies, jaspers, opals and siliceous rocks) and to discard tools that would have been no longer useful. This might well explain the differences in the fragmentation ratio between the northern and the western San Matías Gulf coasts.

The results obtained are in agreement with the expectations derived from the Evolutionary Ecology theory in terms of the predictability of resources for both areas. Thus, the northern coast displays a low risk threshold supported by our analysis that quantitatively demonstrated increased reoccupation of space, higher tool discard rate and exploitation of a wider breadth of raw materials, some of them of medium to poor knapping quality. In contrast, the western coast shows a higher proportion of flakes and cores than tools, but comparatively low tool-type and core diversity. This would correspond to a sporadic occupation of this area, with lower overall resource exploitation along the year and consequently a higher risk threshold.

Regarding the methods of analysis used in this paper, we note that the low variance percentage observed on the first components of the analyses is related to the heterogeneity of the matrix that we use, in which the proportions of some of the tools, cores, and raw materials categories were too low, or with too many double zeros. Therefore, the performance and viability of the method improves when combined with a hierarchical cluster analysis. In such cases, when the first two axes of the factorial analysis describe a low variance percentage, a cluster analysis can be undertaken on the number of dimension necessary to explain a particular percentage in the global variation. In this case, $70 \%$ of the variation that involved the first five dimensions shows a result very similar to that of the first two axes on the factorial analysis, whilst still permitting the separation of these into differentiated subgroups in multivariate space, highlighting a greater number of significant variables. Therefore, the combination of both methods in the case of heterogeneous matrixes would yield significant results.

The use of reduced matrixes concentrating on the most common classes would increase the percentage described by the first two axes. Nevertheless, the main goal of our article was to describe the general resource variability pattern and to explore how these methods works in relation with the technological organization of the hunter-gatherer groups that inhabited San Matías Gulf coast during Late and Middle Holocene.

Even though we considered the sample as temporally homogeneous, the grouping pattern, especially of the smaller cluster, had a temporal underpinning, especially given that it grouped loci around earlier dates. This firmly suggests that the incorporation of time as a factor could improve the explanatory usefulness of this analysis. In previous investigations [15] we proposed that, especially along the northern coast, artifact diversity was not geographically, but chronologically structured, given that samples with similar dates were composed of similar tool proportions, independent of location, or spatial proximity. This could signify that space along the northern coast was used in a relatively homogeneous way across the different periods of marine resource exploitation defined for the area [15] (Table 5). The examination of the temporal parameters of the western coast sample is still pending.

Also, the use of other formational variables, besides fragmentation, such as abrasion, patina or surface of the deposits, along with the relative chronology of these concentrations, could well be used in characterizing much more precisely the chronology of the loci. Furthermore, this method might be very useful in studying loci taking other completely different criteria into consideration. One such could be the anthropic impact on the integrity of the archaeological record given that this method allows to characterize the loci in relation to their proximity to human settlements, obstrusiveness roads, and so forth. This in turn could guide conservation policies pertaining to this ephemeral archaeological record; 
TABLE 5: Main statistical differences between sectors. It is possible to discriminate groups of sites according to some core types, the presence of denticulate, the average of lithic raw materials that were exploited and the fragmentation ratio. These last two variables are the main ones used in differentiating between both areas of the coast.

\begin{tabular}{ll}
\hline Northern coast & Western coast \\
\hline $\begin{array}{l}\text { (i) Higher artifact and core types } \\
\text { diversity, lower proportion of } \\
\text { polyhedral cores. }\end{array}$ & $\begin{array}{l}\text { (i) Lower artifact diversity, } \\
\text { higher proportion of } \\
\text { polyhedral cores. } \\
\text { (ii) Predominant use of locally }\end{array}$ \\
$\begin{array}{ll}\text { (ii) Predominant use of locally } \\
\text { available rocks (DFGR). }\end{array}$ & $\begin{array}{l}\text { available rocks (chalcedonies, } \\
\text { jaspers, and opals). } \\
\text { (iii) Higher fragmentation }\end{array}$ \\
(iii) Lower fragmentation ratio & ratio than in the northern \\
than in the western coast. & coast. \\
\hline
\end{tabular}

this is another aspect on which we are currently working. This last point is gaining increasing relevance against the context of commercial and tourism growth that the area is experiencing, in which diverse infrastructure projects go against the preservation in situ of the archaeological record, rendering any activities which aspire to preserve this record of critical importance.

Finally, the use of multivariate methods allows us to reduce and disaggregate information, and thereby concentrate our interpretations on related subgroups of variables, which in turn informs about more global patterns. As we have mentioned at the beginning of this paper, this work does not replace other uni- or bivariated techniques $([9,14-$ 16], among others), but it complements them. The linkage of these different approaches can help to build a strong base to generate and contrast solid hypothesis that, in turn, bring us closer to the truth underpinning the artifactual assemblages we study.

\section{Acknowledgments}

Thanks to Cecilia Pallo and Maximiliano Bestene for helping us with the design of the figures. Also, the authors thank Dr. Cristian Favier Dubois and Dr. Karen Borrazzo for the suggestions and comments made on this paper. Also, the authors want to thank the anonymous referees whose comments and suggestions helped them to improve this paper. Financial support was provided by grants from CONICET (PIP 112-200801-00756 and PIP 112-201101-00589) and a Ph.D. scholarship (CONICET).

\section{References}

[1] C. F. Dubois and F. Borella, "Contrastes en la costa del golfo: una aproximación al estudio del uso humano del litoral rionegrino en el pasado," in Arqueología de Pescadores y Marisqueadores en Nordpatagonia. Descifrando un Registro de Más de 6.000 Años, F. Borella and M. Cardillo, Eds., pp. 13-42, Dunken, Buenos Aires, Argentina, 2011.

[2] F. Borella, F. Scartascini, and H. Marani, "Explorando la subsistencia humana a partir de la evidencia faunística en la costa rionegrina," in Arqueología de Pescadores y Marisqueadores en
Nordpatagonia. Descifrando un Registro de Más de 6.000 Años, F. Borella and M. Cardillo, Eds., pp. 87-110, Dunken, Buenos Aires, Argentina, 2011.

[3] M. Cardillo, Variabilidad en la manufactura y diseño de artefactos en el área costera patagónica. Un enfoque integrador [dissertation], Facultad de Filosofía y Letras, Universidad de Buenos Aires., Buenos Aires, Argentina, 2009.

[4] "Diversidad artefactual y explotación de materias primas en la Costa Norpatagónica, Río Negro," in Arqueología de Pescadores y Marisqueadores en Nordpatagonia. Descifrando un Registro de Más de 6.000 Años, F. Borella and M. Cardillo, Eds., pp. 67-86, Dunken, Buenos Aires, Argentina, 2011.

[5] C. F. Dubois, F. Borella, L. Manzi et al., "Aproximación regional al registro arqueológico de la costa rionegrina," in Arqueología de la Costa Patagónica. Perspectivas Para la Conservación, I. Cruz and S. Caracotche, Eds., pp. 50-68, Universidad de la Patagonia Austral, Río Gallegos, Argentina, 2008.

[6] L. Manzi, F. Borella, and M. Cardillo, "Distribuciones artefactuales: una aproximación a la estructura espacial del registro arqueológico del litoral atlántico rionegrino," in Arqueología de Pescadores y Marisqueadores en Nordpatagonia. Descifrando un Registro de Más de 6.000 Años, F. Borella and M. Cardillo, Eds., pp. 43-66, Dunken, Buenos Aires, Argentina, 2011.

[7] M. Cardillo and C. F. Dubois, "Una aproximación al uso del espacio en la Costa Norte del Golfo San Matías (Río Negro, Argentina): relaciones entre la evidencia artefactual e isotópica," in Movilidad Y Migraciones. III Jornadas Interdisciplinarias De Historia Y Ciencias Humanas, A. Guiance, Ed., pp. 241-252, CONICET, IMHICIHU, Buenos Aires, Argentina, 2011.

[8] M. Cardillo, C. F. Dubois, F. Scartascini, and L. Lípari, "Una aproximación a la diversidad en la tecnología lítica de la costa Norte del Golfo San Matías, Rio Negro, Argentina," Tras Las huelLAs de la Materialidad. Actas del 16a Congreso NacionAl de Arqueología Argentina, Universidad Nacional de Jujuy, San Salvador de Jujuy, Argentina, pp. 323-328, 2007.

[9] J. Alberti, "Primera exploración de la inversión de trabajo en los conjuntos líticos de la costa norte del golfo San Matías, provincia de Río Negro (Argentina)," LLa Zaranda de Ideas. Revista de Jóvenes Investigadores en Arqueología, vol. 8, no. 2, pp. 83-100, 2012.

[10] C. F. Dubois, C. Stern, and M. Cardillo, "Primera caracterización de los tipos de obsidiana presentes en la costa rionegrina," in Arqueología de la Patagonia - Una Mirada Desde el último Confín, M. Salemme, F. Santiago, M. Álvarez, E. Piana, M. V. Vázquez, and E. Mansur, Eds., pp. 349-359, Editorial Utopías, Ushuaia, Argentina, 2009.

[11] "Distribución de los conjuntos líticos asignables al holoceno medio-tardío en la costa norte del golfo San Matías, provincia de Río Negro, Argentina," in Tendencias Teóricometodológicas y Casos de Estudio n la Arqueología de la Patagonia, F. Zangrando, R. Barberena, A. Gil et al., Eds., pp. 63-69, Museo de Historia Natural de San Rafael, San Rafael, Argentina, 2013.

[12] B. Escoffier and J. Pagès, Analyse Factorielles Simples Et Multiples: Objectifs, Méthodes Et Interprétation, Dunod, Paris, France, 1998.

[13] J. Pagès, "Analyse factorielle multiple appliquée aux variables qualitatives et aux données mixtes," Statistique Appliqué, vol. 50, no. 4, pp. 5-37, 2002.

[14] J. Alberti, "Fuentes de rocas y usos de materias primas líticas en la costa norte del golfo San Matías (provincia de Río Negro, Argentina)," Intersecciones en Antropología, vol. 13, pp. 237-249, 2012. 
[15] M. Cardillo and J. Alberti, "Diversidad en el instrumental lítico y uso del espacio durante el Holoceno medio y tardío en la costa norte del golfo San Matías (Río Negro, Argentina)," Magallania. In press.

[16] "Raw material availability and distribution, and human exploitation strategies in coastal North Patagonia, Río Negro province, Argentina," in Proceedings of the 5th Arheoinvest Symposium "Stories Written in Stone" International Symposium on Chert and Other Knappable Materials, University of Iasi.

[17] S. Schlanger, "Recognizing persistent places in Anasazi settlement systems," in Space, Time and Archaeological Landscapes, J. Rossignol and L. Wandsnider, Eds., pp. 91-112, Plenum Press, New York, NY, USA, 1992.

[18] J. Shiner, "Persistent places: an approach to the interpretation of assemblage variation in deflated surface stone artifact distributions from western New South Wales, Australia," in Terra Australis 28. New Directions in Archaeological Science, A. Fairbairn, S. O'Connorand, and B. Marwick, Eds., ANU Press, Acton, Australia, 2011.

[19] S. J. Holdaway, P. C. Fanning, and D. C. Witter, "Prehistoric aooriginal occupation of the rangelands: interpreting the surface archaeological record of far Western New South Wales, Australia," The Rangeland Journal, vol. 22, no. 1, pp. 44-57, 2000.

[20] E. Camilli and J. Ebert, "Artifact reuse and recycling in continuous surface distributions and implications for interpreting land use pattern," in Space, Time and Archaeological Landscapes, J. Rossignol and L. Wandsnider, Eds., pp. 113-136, Plenum Press, New York, NY, USA, 1992.

[21] S. Holdaway, J. Shiner, and P. Fanning, "Hunter-gatherers and the archaeology of discard behavior: an analysis of surface stone artifacts from Sturt National Park, Western New South Wales, Australia," Asian Perspectives, vol. 43, no. 1, pp. 34-72, 2004.

[22] B. Winterhalder and E. Smith, "Evolutionary ecology and the social sciences," in Evolutionary Ecology and Human Behavior, E. Smith and B. Winterhalder, Eds., pp. 3-23, Aldine de Gruyter, New York, NY, USA, 1992.

[23] B. Winterhalder and E. A. Smith, "Analyzing adaptive strategies: human behavioral ecology at twenty-five," Evolutionary Anthropology, vol. 9, no. 2, pp. 51-72, 2000.

[24] C. B. Bousman, "Hunter-gatherer adaptations, economic risk and tool design," Lithic Technology, vol. 18, no. 1-2, pp. 59-86, 1993.

[25] D. Bamforth and P. Bleed, "Technology, flaked stone technology, and risk," Archeological Papers of the American Anthropological Association, vol. 7, no. 1, pp. 109-139, 1997.

[26] R. Torrence, "Retooling: towards a behavioral theory of stone tools," in Time, Energy and Stone Tools, R. Torrence, Ed., pp. 5766, Cambridge University Press, Cambridge, UK, 1989.

[27] C. B. Bousman, "Coping with risk: Later stone age technological strategies at Blydefontein Rock Shelter, South Africa," Journal of Anthropological Archaeology, vol. 24, no. 3, pp. 193-226, 2005.

[28] J. L. . Lanata and L. Borrero, "Riesgo y arqueología," in Arqueología de Cazadores Recolectores. Límites, Casos y Aperturas, J. L. Lanata and L. Borrero, Eds., pp. 129-143, Buenos Aires, Argentina, 1994.

[29] J. Charlin, "Utilización de materias primas líticas en el campo volcánico Pali Aike(Pcia. de Santa Cruz, Argentina). Una primera aproximación a partir del análisis de núcleos," Werken, vol. 7, pp. 39-55, 2005.

[30] J. Symons, "Obsidian artefacts and land-use in the midHolocene of the Willaumez Peninsula, Papua New Guinea," Australian Archaeology, vol. 57, pp. 128-134, 2003.
[31] D. Bamforth, "Technological organization and hunter-gatherer land use: a California example," American Antiquity, vol. 56, no. 2, pp. 216-234, 1991.

[32] M. Cardillo and F. Scartascini, "Tendencias observadas en las estrategias de explotación de recursos líticos en el Golfo de San Matías, provincia de Rio Negro, Argentina," in Arqueología de Fuego-Patagonia. Levantando Piedras, Desenterrando Huesos... Y Develando Arcanos, F. Morello, M. Martinic, A. Prieto, and G. Bahamonde, Eds., pp. 117-127, Ediciones CEQUA, Punta Arenas, Chile, 2007.

[33] C. F. Dubois, F. Borella, and R. Tykot, "Explorando tendencias en el uso humano del espacio y los recursos en el litoral rionegriono (Argentina) durante el Holoceno medio y tardío," in Arqueología de la Patagonia-Una Mirada Desde el último Confín, M. Salemme, F. Santiago, M. Álvarez, E. Piana, M. V. Vázquez, and E. Mansur, Eds., pp. 985-997, Editorial Utopías, Ushuaia, Argentina, 2009.

[34] L. Lípari and M. Cardillo, "Una primera aproximación a las estrategias de explotación de materias primas líticas en la costa oeste del golfo San Matías (Río Negro)," in Actas del 17 Congreso Nacional de Arqueología Argentina, R. B. Bárcena and H. Chiavazza, Eds., pp. 15-18, Facultad de Filosofía y Letras (Universidad Nacional de Cuyo)_INCIHUSA (CONICET), Mendoza, Argentina, 2010.

[35] D. E. González and E. Malagnino, "Geomorfología de la provincia de Río Negro," in 9 Congreso Geológico Argentino, San Carlos de Bariloche, Argentina, 1984.

[36] L. Manzi, C. Favier Dubois, and F. Borella, "Identificación de agentes perturbadores y estrategias tendientes a la conservación del patrimonio arqueológico en la costa del Golfo de San Matías, provincia de Río Negro," Intersecciones en Antropología, vol. 10, pp. 3-16, 2009.

[37] F. Borella, "Dónde están los lobos en la costa norpatagónica? Explorando vías para resolver el registro arqueofaunístico," Werken, vol. 9, pp. 97-114, 2006.

[38] C. F. Dubois, "Hacia una cronología del uso del espacio en la costa norte del golfo San Matías (Río Negro, Argentina): sesgos geológicos e indicadores temporales," in Tendencias Teórico-metodológicas y Casos de Estudio en la Arqueología de la Patagonia, F. Zangrando, R. Barberena, A. Gil et al., Eds., pp. 87-96, Museo de Historia Natural, San Rafael, Argentina, 2013.

[39] J. Oresanz, A. Escofet, and V. Scarabino, "Relevamiento y tipificación de las comunidades bentónicas," in Relevamiento ecológico y tipificación de las comunidades del litoral marítimo de la provincia de Río Negro, con especial referencia al establecimiento de áreas de cultivo para especies de interés comercial, Instituto de Biología Marina, Asesoría de Desarrollo de Río Negro y Consejo Federal de Inversiones, Río Negro, Argentina, 1973.

[40] F. Borella, C. Mariano, and C. F. Dubois, "Procesos tafonómicos en restos humanos en superficie en la localidad arqueológica de Bajo de la Quinta, Golfo SanMatías (Río Negro)," in Arqueología de Fuego-Patagonia. Levantando Piedras, Desenterrando Huesos... y Develando Arcanos, F. Morello, M. Martinic, A. Prieto, and G. Bahamonde, Eds., pp. 403-410, Ediciones CEQUA, Punta Arenas, Chile, 2007.

[41] L. Binford, "Organization and formation processes: looking at curated technologies," Journal of Anthropological Research, vol. 35, no. 3, pp. 255-273, 1979.

[42] E. Aragón and N. Franco, "Características de rocas para la talla por percusión y propiedades petrográficas," in Anales Del Instituto De La Patagonia, vol. 25 of Serie Ciencias Humanas, pp. 187-189, Universidad de Magallanes, Punta Arenas, Chile, 1997. 
[43] M. Nelson, "The study of technological organization," Archaeological Method and Theory, vol. 3, pp. 57-100, 1991.

[44] M. J. Shott, "Size dependence in Assemblage measures: essentialism, materialism, and "SHE" analysis in archaeology," American Antiquity, vol. 75, no. 4, pp. 886-906, 2010.

[45] L. R. Taylor, "Aggregation, variance and the mean," Nature, vol. 189, no. 4766, pp. 732-735, 1961.

[46] P. Legendre and E. D. Gallagher, "Ecologically meaningful transformations for ordination of species data," Oecologia, vol. 129, no. 2, pp. 271-280, 2001.

[47] P. Legendre and L. Legendre, Numerical Ecology, Elsevier, Amsterdam, The Netherlands, 1998.

[48] D. Borcard, F. Gillet, and P. Legendre, "Numerical ecology with R," Journal of Agricultural, Biological, and Environmental Statistics, vol. 17, no. 2, pp. 308-309, 2011.

[49] C. Aschero, "Ensayo para una clasificación morfolÓgica de artefactos líticos aplicada a estudios tipolÓgicos comparativos," CONICET, 1989.

[50] "Ensayo para una clasificación morfológica de artefactos líticos. Appendix A and B," CONICET, 1983.

[51] F. Husson, J. Josse, and J. Pagès, "Principal component methods -hierarchical clustering-partitional clusterin: why would we need to choose for visualizing data?” Tech. Rep., 2010.

[52] J. Josse, J. Pagès, and F. Husson, "Testing the significance of the RV coefficient," Computational Statistics and Data Analysis, vol. 53, no. 1, pp. 82-91, 2008.

[53] S. Lê, J. Josse, and F. Husson, "FactoMineR: an R package for multivariate analysis," Journal of Statistical Software, vol. 25, no. 1, pp. 1-18, 2008.

[54] Development Core Team, "R: a language and environment for statistical computing," reference index version 2. 2. 1., R Foundation for Statistical Computing, Vienna, Austria, 2005, http://www.R-project.org/.

[55] K. Borrazzo, Arqueología de los esteparios fueguinos. Tafonomía lítica y tecnología en el norte de Tierra del Fuego [dissertation], Facultad de Filosofía y Letras, Universidad de Buenos Aires, Buenos Aires, Argentina, 2010. 

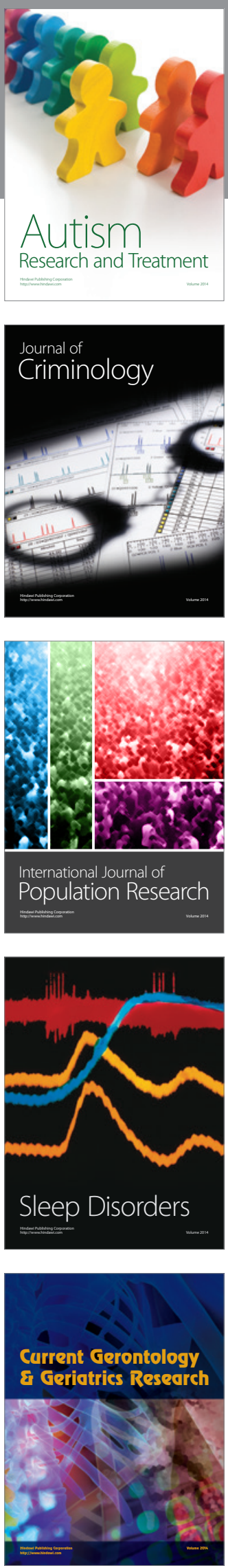
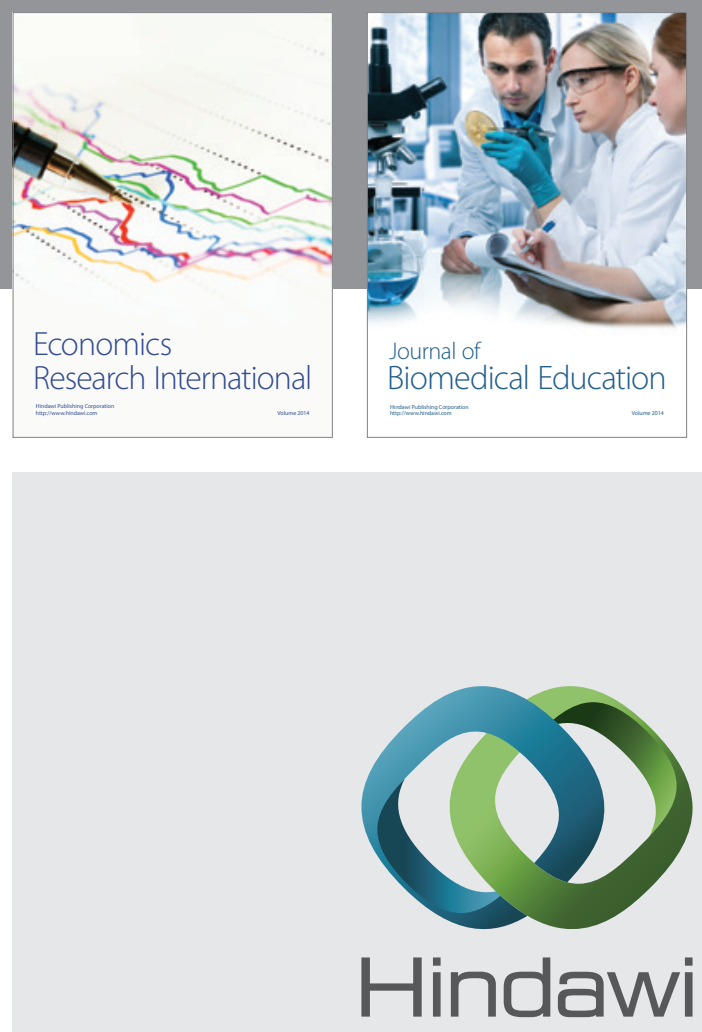

Submit your manuscripts at

http://www.hindawi.com
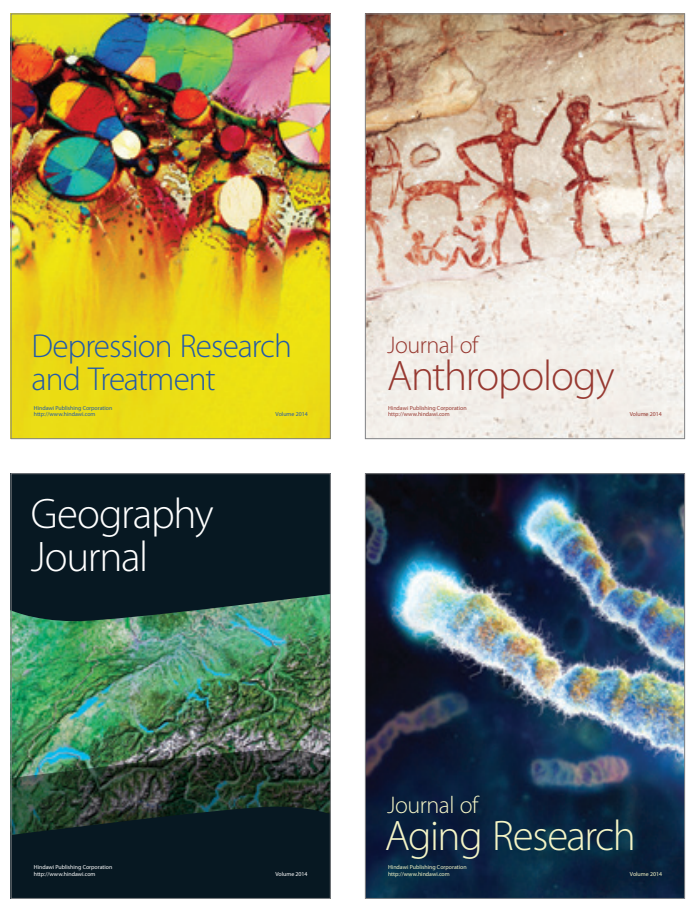
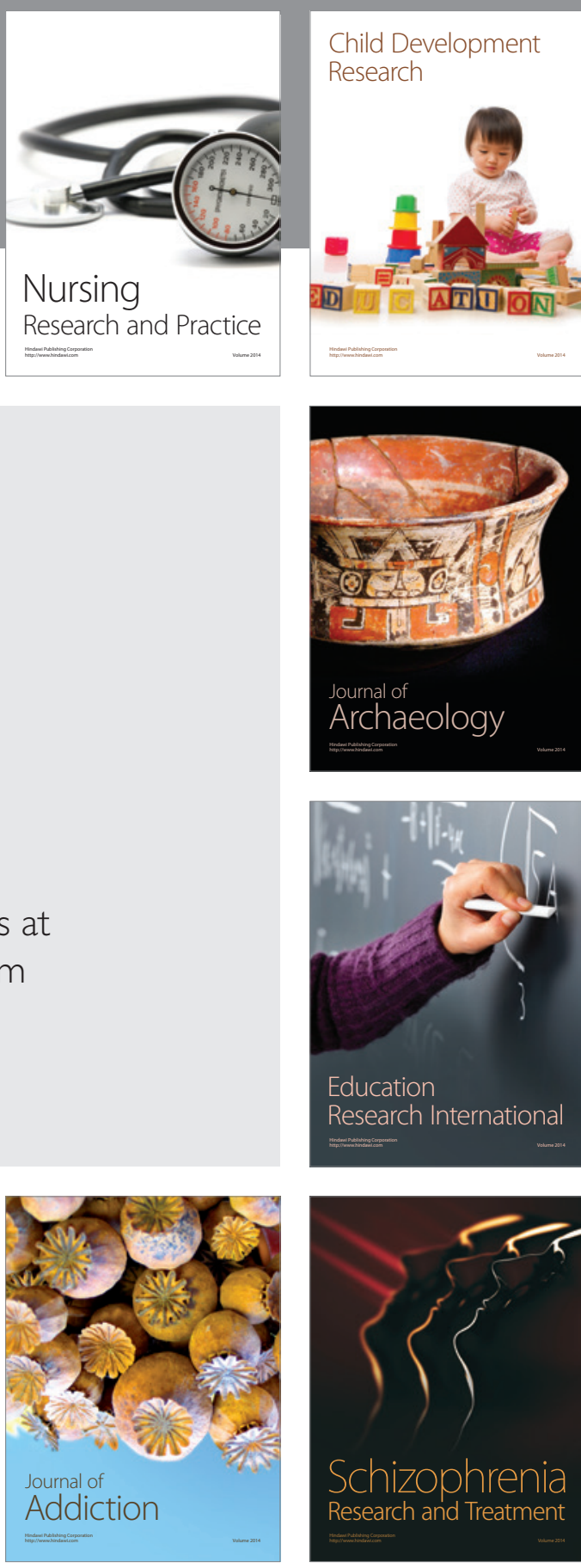

(D)
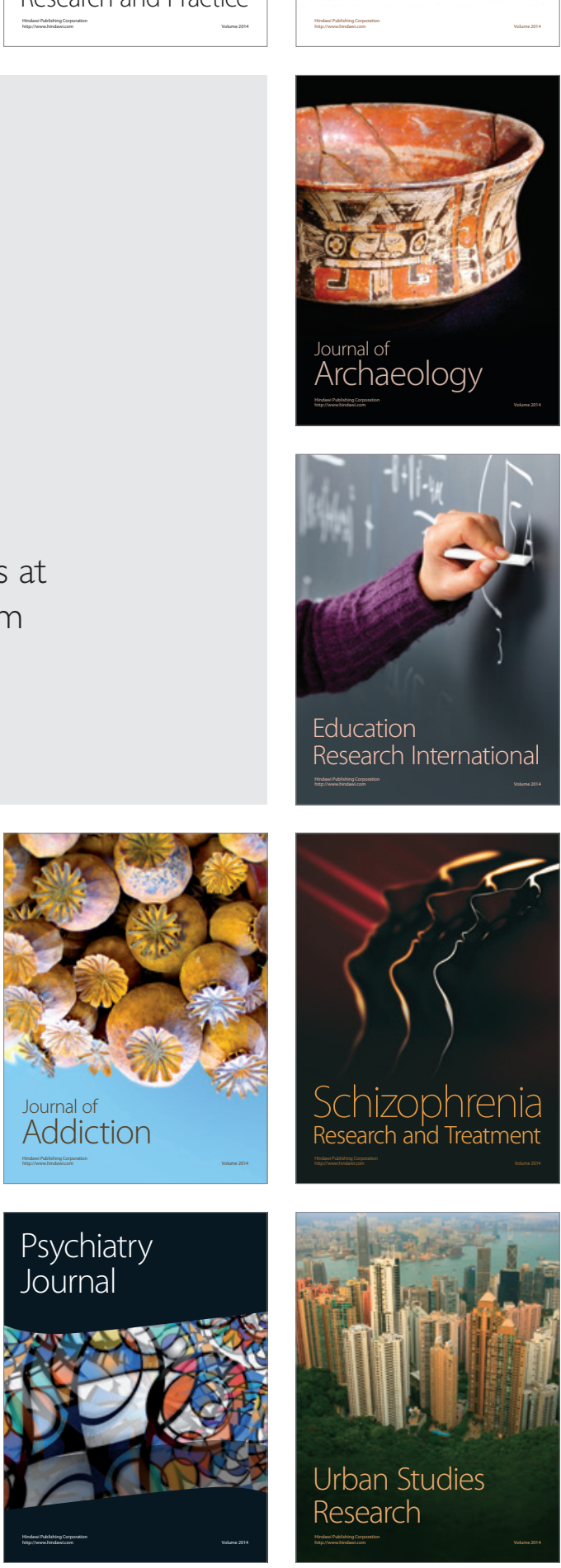